\section{Spektralphotometrische Bestimmung von Carbonylverbindungen über die 2,4-Dinitrophenylhydrazone}

Spectrophotometric Determination of Carbonyl Compounds via the 2,4-Dinitrophenylhydrazones

Best. von Carbonylverbindungen mit 2,4-Dinitrophenylhydrazin; Spektralphotometrie

I. Ognyanov und E. Tsankova

Inst. für Org. Chemie, Bulgar. Akad. Wissenschaften, Sofia, Bulgarien

Eingegangen am 26. Februar 1973; neve Fassung 28. Mai 1973

Bei dem hier vorgeschlagenen Verfahren wird die Probelösung mit überschüssigem 2,4-Dinitrophenylhydrazin versetzt, der Uberschuß mit Salicylaldehyd oder mit p-Hydroxybenzaldehyd gebunden, das entstandene Hydrazon sowie überschüssiges Reagens durch wäßrige Natronlauge entfernt und in der verbleibenden (benzolischen) Lösung das darin noch enthaltene Hydrazon der gesuchten Carbonylverbindung photometrisch gemessen. Dies erfordert allerdings, daß das betreffende Hydrazon gegen alkalische Lösung stabil ist. Zum Beispiel bei folgenden Verbindungen trifft das zu: Formaldehyd, Methylnonylacetaldehyd, Citral, Pulegon, Carvon, Campher und Anisaldehyd.

\section{Manganimetric Determination of Thioureas}

Manganimetrische Bestimmung von Thioharnstoffen

Best. von Thioharnstoffen; Volumetrie; manganimetrisch

Balbir Chand Verma and Swatantar Kumar

Department of Chemistry, Punjabi University, Patiala, India

Received November 7, 1972; revised April 26, 1973

A known weight of each compound (thiourea, methyl thiourea, ethyl thiourea, n-propyl thiourea, iso-propyl thiourea, $n$-butyl thiourea, iso-butyl thiourea, o-tolyl thiourea, o-methoxyphenyl thiourea or o-ethoxyphenyl thiourea) was taken in a titration flask. In case of thiourea and its alkyl derivatives, sufficient water and enough of sulphuric acid to keep normality of the solution at $0.5 \mathrm{~N}$ and its volume at $70 \mathrm{ml}$, were added. Each aryl derivative was dissolved in $18 \mathrm{~N}$ sulphuric acid and the solution diluted with water to bring its normality to 3 to $4 \mathrm{~N}$. In case of thiourea and its alkyl derivatives $0.5 \mathrm{ml}$ and in case of aryl derivatives $0.2 \mathrm{ml}$ of $2 \%$ potassium iodide solution were also added. The solution in each case was cooled to room temperature and titrated with $0.05 \mathrm{~N}$ manganic sulphate solution. The end-point was detected visually by using amylose $0.2 \mathrm{ml}$ of $1 \%$ aqueous solution) as an indicator; the solution acquired a blue colour at the end-point.
Das Verfahren gestattet die Bestimmung kleiner Mengen von Carbonylverbindungen mit $20-200 \mu \mathrm{g}$ Carbonylsauerstoff. Eine Bestimmung erfordert 15 bis 20 min. Reaktionsfähige Carbonylverbindungen ohne Phenol- oder Carboxylgruppe können erfaßt werden. Die Methode wurde anhand von Anisaldehyd geprüft. Dabei ergab sich eine Standardabweichung von $S=3,01 \cdot 10^{-2}$ und ein Variationskoeffizient von $V=1,9 \%$.

Durchführung. Die Probe verdünnt man mit Benzol so weit, daB die Konzentration $0,5-5 \%$ beträgt. $0,1 \mathrm{ml}$ der Lösung versetzt man im Reagensglas mit eingeschliffenem Glasstöpsel mit 0,3 ml 2,4-Dinitrophenylhydrazinlösung (s.u.), schüttelt und erhitzt den Boden des Glases 1-2 min im Wasserbad. Nach dem Abkühlen gibt man 0,3 ml Salicylaldehyd zu, schüttelt wieder und erwärmt. Nach erneutem Abkühlen fügt man $1 \mathrm{ml}$ Wasser, $10 \mathrm{ml}$ Benzol sowie $3 \mathrm{ml}$ $20 \%$ ige Natronlauge zu, schüttelt $1 \mathrm{~min}$ heftig, läßt 3 bis $4 \mathrm{~min}$ stehen, entnimmt $0,1 \mathrm{ml}$ der oberen Benzolschicht, verdünnt 30-60 mal mit Benzol und mißt die Absorption bei $385 \mathrm{~nm}$ gegenüber einer Blindprobe. Die Färbung ist bis zu $1 \mathrm{~h}$ stabil. Die Resultate entnimmt man einer analog aufgestellten Eichkurve.

Herstellung der Reagenslösung. 0,4 g 2,4-Dinitrophenylhydrazin versetzt man mit $2 \mathrm{ml}$ konz. Schwefelsäure sowie $3 \mathrm{ml}$ dest. Wasser und verdünnt mit $10 \mathrm{ml}$ aldehydfreiem Äthanol. 4 Wochen in dunklem Gefäß haltbar.

Prof. Dr. I. Ognyanov

Institut für Organische Chemie

Bulgarische Akademie der Wissenschaften

Sofia 13, Bulgarien

In potentiometric titrations, a platinum wire immersed in the solution to be titrated was used as an oxidationreduction electrode and this was coupled with a saturated calomel electrode. At the equivalence point a sharp jump in potential was observed in each titration. A series of potentiometric titrations was performed with different amounts of each compound.

From the volume of standard manganic sulphate solution used corresponding to the end-point in visual and potentiometric titrations, the amount of each compound was calculated. The thioureas are quantitatively oxidised to the corresponding disulphides with a single-electron change.

The results of our experiments showed that the above mentioned thioureas in the range of 5 to $60 \mathrm{mg}$ can be determined by direct visual and potentiometric titrations with manganic sulphate $(0.05 \mathrm{~N})$ solution with a maximum deviation of $0.67 \%$ (visual) and $0.58 \%$ (potentiometric), respectively.

Acknowledgement. The authors thank Council of Scientific and Industrial Research (India) for the award of research fellowship to one of them (S. K.).

Dr. Balbir Chand Verma

Department of Chemistry

Punjabi University

Patiala, India 